ШЕВЦОВА К.В.

\title{
ПОВНОВАЖЕННЯ ПРОКУРОРА ЩОДО ВИЗНАЧЕННЯ ПІДСЛІДНОСТІ ТА МІСЦЯ ПРОВЕДЕННЯ ДОСУДОВОГО РОЗСЛІДУВАННЯ
}

Стаття присвячена аналізу законодавчих положень, якими унормовано діяльність прокурора щодо визначення підслідності та місця проведення досудового розслідування. Проаналізовано відповідні положення КПК України, Закону України «Про прокуратуру», а також наукові праці вчених із досліджуваного питання. Підтримано наукову позицію щодо того, що чіткий порядок визначення прокурором підслідності та передачі матеріалів кримінального провадження з одного органу досудового розслідування до іншого, зокрема за її зміни, є запорукою досягнення завдань кримінального провадження. Водночас КПК України 3 цього питання містить певні прогалини й неточності, які потребують вирішення, що в подальшому дасть змогу уникнути визнання доказів недопустимими. Констатовано, що саме на прокурора як процесуального керівника покладено обов'язок правильного й точного визначення підслідності відповідного кримінального правопорушення задля спрямування відповідних матеріалів за належністю. Визначено, що на законодавчому рівні не встановлено граничного терміну, протягом якого прокурор має вирішити питання про підслідність кримінальних проваджень. Також приділено увагу тому, що в КПК України не встановлено час на вирішення прокурором питання щодо місця проведення досудового розслідування. Підкреслено, що такі законодавчі прогалини та неточності значно знижують ефективність здійснення досудового розслідування у кримінальних провадження, можуть призвести до суттєвих порушень вимог кримінального процесуального закону, сприяють затягуванню строків досудового розслідування тощо. Зроблено висновок про необхідність удосконалення положень КПК України з цих питань, що забезпечить одноманітність правозастосовної діяльності, а також сприятиме визнанню доказів допустимими у кримінальному провадженні.

Ключові слова: прокурор, підслідність, місие проведення досудового розслідування, кримінальне провадження.

The article is devoted to the analysis of the legislative provisions that normalize the activities of the prosecutor to determine the jurisdiction and the place of the pre-trial investigation. The relevant provisions of the Code of Criminal Procedure of Ukraine, the Law of Ukraine "On the Prosecutor's Office", as well as the scientific works of scientists from the issue under study, are analyzed. The scientific position was supported that a clear procedure for determining the prosecutor's jurisdiction and transferring the materials of criminal proceedings from one pre-trial investigation body to another, in particular in the event of a change, is the key to achieving the objectives of criminal proceedings. At the same time, the Code of Criminal Procedure of Ukraine on this issue contains certain gaps and inaccuracies that need to be addressed, which in the future will avoid the recognition of evidence as unacceptable. It was stated that it was the prosecutor, as the procedural leader, who was entrusted with the duty to correctly and accurately determine the jurisdiction of the corresponding criminal offense for sending materials by affiliation. It has been determined that no time limit has been established at the legislative level during which the prosecutor must decide on the jurisdiction of criminal proceedings. It is also noted that the Criminal Procedure Code of Ukraine does not establish time for the prosecutor to decide on the place of the pre-trial investigation. It is emphasized that such legislative gaps and inaccuracies significantly reduce the effectiveness of the pre-trial in-

(C) ШЕВЦОВА К.В. - аспірант (Харківський національний університет внутрішніх справ), керівник (Харківська місцева прокуратура № 1) 
vestigation of criminal proceedings, can lead to significant violations of the requirements of the criminal procedural law, and contribute to the delay of the pre-trial investigation and the like. It is concluded that it is necessary to improve the provisions of the Code of Criminal Procedure of Ukraine on these issues, which will ensure uniformity of law enforcement activities, and will also help to recognize evidence admissible in criminal proceedings.

Key words: prosecutor, jurisdiction, place of pre-trial investigation, criminal proceedings.

Вступ. Дослідження процесуальних повноважень прокурора щодо реалізації ним загальних положень досудового розслідування нерозривно пов'язано з регламентацією підслідності та визначення місця проведення досудового розслідування. Важливість цього питання перш за все можна пояснити тим, що від додержання зазначених вимог значною мірою залежить ефективність здійснення досудового розслідування. Більш того, чітка регламентація підслідності на рівні процесуального кодифікованого закону є однією з вагомих гарантій дотримання прав і свобод людини під час здійснення кримінального провадження, оскільки метою цього інституту є забезпечення права особи на об'єктивне й неупереджене розслідування i, як наслідок, гарантування передбаченого Конвенцією про захист прав людини і основоположних свобод права особи на справедливий суд [1, с. 4].

Постановка завдання. Саме тому задля досягнення цієї мети велике значення має процесуальна діяльність прокурора з визначення підслідності, що, відповідно до ч. 9 ст. 216 КПК України, входить до кола його обов'язків.

Окремі питання, пов’язані з проблематикою підслідності кримінальних проваджень, досліджувались у працях таких науковців, як С.Г. Волкотруб, В.О. Гринюк, В.Г. Дрозд, О.В. Каплина, А.В. Лапкін, Л.М. Лобойко, Н.В. Марчук А.А. Омаров, М.А. Погорецький, С.О. Січко, О.Ю. Татаров, О.О. Цимбалістенко.

Результати дослідження. Сьогодні чинний КПК України не містить нормативного визначення підслідності, у зв'язку з чим деякі науковці звертають увагу на те, що як у доктрині кримінального процесу, так і в законодавстві одночасно вживаються терміни «підслідність», «юрисдикція», «компетенція», «повноваження».

Слід підтримати наукову точку зору щодо того, що підслідність - це сукупність правил, згідно з якими визначається орган досудового розслідування, уповноважений здійснювати розслідування конкретного кримінального провадження $[2$, с. 33,$35 ; 3$, с. 62]. Як цілком слушно підкреслила В.Г. Дрозд, підслідність у кримінальному провадженні є самостійним інститутом кримінального процесуального права, змістом якого є сукупність норм, що регламентують відносини під час визначення компетенції конкретного органу, уповноваженого на здійснення досудового розслідування, задля виконання завдань кримінального провадження [4, с. 138].

Повноваження прокурора у кримінальному провадженні зосереджені не тільки у ст. 36 КПК України, адже процесуальна діяльність прокурора щодо визначення підслідності також визначена у положеннях ч. 7 ст. 214 та ч. 2 ст. 218 КПК України, але й у ч. 3 ст. 218 КПК, що визначає місце проведення досудового розслідування та роль прокурора як представника сторони обвинувачення у цьому процесі. Зазначені повноваження безпосередньо пов'язані як з іншими повноваженнями прокурора, так і між собою.

Крім того, досить важливим $є$ правильне визначення місця проведення досудового розслідування, оскільки це безпосередньо впливає на процес збирання доказів, а саме дотримання такої їх властивості, як допустимість. Зокрема, в положенні ч. 1 ст. 86 КПК України чітко закріплено, що докази визначаються допустимими, якщо вони отримані в порядку, встановленому цим Кодексом. Інакше, як визначено в ч. 2 ст. 86 КПК України, недопустимий доказ не може бути використаний під час прийняття процесуальних рішень.

У своєму дослідженні О.О. Цимбалістенко встановив, що щодо додержання критеріїв або умов, наявність або відсутність яких зумовлює оцінювання прокурором стану законності у відповідній сфері, визначення ним підслідності та місця проведення досудового розслідування входить до складу предмета прокурорського нагляду за додержанням законів, а також є стандартом прокурорського нагляду за додержанням законів на початковому етапі досудового розслідування $[5$, c. 8,69$] .3$ такою позицією варто погодитися, а також слід додати цілком доречне твердження А.В. Лапкіна, який також включає до предмета нагляду на початковому етапі досудового розслідування питання, пов'язані з підслідністю [6, с. 95]. 
В цьому контексті наголосимо на деяких проблемах, які можуть виникати у зв'язку з виконанням прокурором вимог закону стосовно визначення підслідності. По-перше, вони можуть виникати у зв'язку з неправильною кваліфікацією кримінального правопорушення, що $є$ досить поширеним явищем на етапі внесення відомостей до СРДР. По-друге, вони стосуються застосування положень ч. 9 ст. 216 КПК України, згідно з якими у кримінальних провадженнях щодо злочинів, передбачених ст. ст. 209, 209-1 КК України, досудове розслідування здійснюється слідчим того органу, який розпочав досудове розслідування. Оскільки сьогодні прокуратура досудове розслідування не здійснює, в цьому разі прокурору необхідно визначити підслідність таких кримінальних правопорушень фактично на власний розсуд. Отже, як у першому, так і в другому випадках в умовах невизначеної або спірної кваліфікації злочину прокурори найчастіше доручають проведення досудового розслідування слідчим підрозділам Національної поліції, які, згідно 3 ч. 1 ст. 216 КПК, мають найбільш широку, універсальну підслідність.

До переліку умов, які у своїй сукупності визначають законність початку досудового розслідування, в науковій та юридичній літературі відносять різні фактори. Зокрема, Н.В. Марчук вважає, що на цьому етапі прокурор має забезпечити виконання вимог ст. 214 КПК України, передусім стосовно порядку внесення даних до СРДР, строків цих дій, повноти відомостей, визначення підслідності [7, с. 17]. Задля уникнення затягування початку досудового розслідування внаслідок тих чи інших причин законодавець у ст. 214 КПК України передбачив обов’язок слідчого своєчасно внести відомості про кримінальне правопорушення до ЄРДР та розпочати проведення досудового розслідування, провести всі можливі та необхідні слідчі (розшукові) дії до моменту, доки прокурор не визначить іншу підслідність (ч. 2 ст. 218 КПК). Про початок досудового розслідування кримінальних правопорушень, які слідчому не підслідні, останній повідомляє прокурору у повідомленні про початок досудового розслідування. Ознайомившись зі змістом повідомлення та виявивши факт розслідування слідчим кримінального правопорушення, що не віднесено до його підслідності, прокурор має винести постанову про визначення територіальної підслідності, в якій відобразити відомості про обставини кримінального провадження; орган досудового розслідування, якому, відповідно до ст. 216 КПК України, підслідне розслідування цього кримінального правопорушення; місце проведення досудового розслідування та слідчий підрозділ, уповноважений здійснити кримінальне провадження. Відомості, зазначені в постанові прокурора про визначення територіальної підслідності, заносяться до ЄРДР.

Таким чином, вищезазначене свідчить про те, що порушення територіальної чи предметної підслідності під час звернення із заявою або повідомлення про кримінальну відповідальність не є підставою для відмови в іiї прийнятті та реєстрації.

Відповідно до ч. 9 ст. 218 КПК України, якщо під час досудового розслідування буде встановлено інші злочини, вчинені особою, щодо якої ведеться досудове розслідування, або іншою особою, якщо вони пов'язані зі злочинами, вчиненими особою, щодо якої ведеться досудове розслідування, і які не підслідні тому органу, який здійснює у кримінальному провадженні досудове розслідування, прокурор, який здійснює нагляд за досудовим розслідуванням, за неможливості виділення цих матеріалів в окреме провадження своєю постановою визначає підслідність всіх цих злочинів. Варто пам'ятати про те, що, згідно з ч. 5 ст. 218 КПК України, спори про підслідність вирішує керівник органу прокуратури вищого рівня. У цьому контексті заслуговує на увагу твердження В.Г. Дрозд про те, що питання про вирішення спорів про підслідність логічно було б розмістити у ст. 216 КПК України, де унормовано порядок визначення підслідності, а не у ст. 218 КПК України, як це передбачено сьогодні. На цій основі вчена запропонувала внести відповідні зміни до положень КПК [4, с. 145, 147-148], що ми повністю підтримуємо.

Зазначимо, що тоді, коли слідчому із заяви, повідомлення або інших джерел стало відомо про обставини, що можуть свідчити про кримінальне правопорушення, розслідування якого не віднесене до його компетенції, вітчизняне кримінальне процесуальне законодавство будь-яких активних дій від нього для зміни підслідності не вимагає. Отже, з цього випливає, що визначення підслідності кримінального правопорушення належить виключно до повноважень процесуального керівника. Рішення про будь-яку зміну підслідності (незалежно від підстав такої зміни) належить до компетенції прокурора як суб'єкта, що здійснює нагляд за законністю діяльності органів досудового розслідування [8, с. 115]. Водночас чинний КПК України не визначає процесуального порядку та строків розгляду питань, пов'язаних зі зміною підслідності прокурором та передачею наявних матеріалів кримінального провадження для проведення розслідування іншим органом досудового розслідування. 
У практичній площині це питання здебільшого вирішується самостійно процесуальним керівником на підставі внутрішнього переконання. Так, О.Ю. Татаров як приклад наводить непоодинокі випадки, коли прокурор своєю постановою, мотивуючи це правом визначення підслідності за будь-яким органом досудового розслідування, в порушення вимог щодо виключності предметної підслідності, якою визначено компетенцію слідчого окремого органу досудового розслідування, змінює підслідність та доручає розслідування слідчому підрозділу іншому органу. Наприклад, досудове розслідування про державну зраду прокурор доручає здійснювати органам Військової прокуратури чи органам поліції [9]. Стан таких речей свідчить про необхідність на законодавчому рівні вдосконалити правову регламентацію порядку зміни підслідності з урахуванням виключних повноважень прокурора з цих питань. Це, звісно, стане запорукою унеможливлення зловживання окремими прокурорами покладених на них обов'язків щодо визначення підслідності.

Слід звернути увагу на той факт, що в КПК України законодавцем не передбачено чіткого процесуального порядку заміни прокурора у зв'язку з передачею кримінального провадження іншому органу досудового розслідування. 3'ясуємо це на прикладі. Так, не виключені випадки, коли під час здійснення досудового розслідування у так званих фактових кримінальних провадженнях, тобто коли відомостей про особу, яка вчинила кримінальне правопорушення немає, згодом з'ясовується, що нею є особа, вказана у переліку осіб, визначених у ч. 5 ст. 214 КПК України (предметна підслідність НАБУ). Відомо, що підслідність НАБУ є виключною, а КПК України забороняє доручати здійснення досудового розслідування кримінального правопорушення, віднесеного до підслідності НАБУ, іншому органу досудового розслідування. У цьому разі матиме місце передача кримінального провадження до НАБУ процесуальним керівником, якщо підслідність за НАБУ стане очевидною і не виникне спору про підслідність. Якщо в такому кримінальному провадженні виникає спір про підслідність, то він має вирішуватися відповідно до ч. 5 ст. 218 КПК України, зокрема керівником органу прокуратури вищого рівня. Спір про підслідність у кримінальному провадженні, яке може належати до підслідності НАБУ, вирішує Генеральний прокурор України або його заступник.

Окремо зупинимось на повноваженні прокурора, яке пов'язано з визначенням підслідності кримінального правопорушення у разі проведення досудового розслідування слідчим, до компетенції якого воно не віднесене (ч. 2 ст. 218 КПК). На наш погляд, попри те, що ця норма вміщена у ст. 218 КПК «Місце проведення досудового розслідування», вона все ж таки стосується не тільки порушень вимог цієї статті стосовно місця проведення досудового розслідування, але й порушення правил підслідності, передбачених у ст. 216 КПК. Подібні ситуації є досить поширеними насамперед у зв'язку з тим, що більшість заяв і повідомлень про кримінальні правопорушення спрямовується до підрозділів Національної поліції, зокрема таких, які не віднесені до їх підслідності. При цьому прокурору слід враховувати, що вирішення питань про підслідність покладається відомчими актами на уповноважених службових осіб чергових частин органів поліції. 3 огляду на це перевірці прокурора підлягає обов'язок таких осіб за рішенням керівника органу (підрозділу) поліції або особи, яка виконує його обов'язки, зареєструвати відомості про виявлене кримінальне правопорушення в ITC ІПНП (журналі СО за тимчасової відсутності технічних можливостей внесення таких відомостей до ІТС ІПНП) та невідкладно, але не пізніше 24 годин реєстрації передати до органу досудового розслідування для внесення відповідних відомостей до ЄРДР або передання цих відомостей до органів (підрозділів) поліції нижчого рівня та їх внесення до ЄРДР, а в міжрегіональних територіальних органах поліції та їх територіальних (відокремлених) підрозділах - до органів (підрозділів) поліції, на території обслуговування яких сталась така подія, для прийняття відповідних рішень та внесення до ЄРДР [10].

Розглядаючи питання про визначення прокурором підслідності кримінального правопорушення, маємо вказати на необхідність законодавчої конкретизації кола суб'єктів такої діяльності, що сприятиме більш повному забезпеченню швидкого, повного та неупередженого досудового розслідування. Така потреба зумовлена тим, що з аналізу положень ч. 1 ст. 15 Закону України «Про прокуратуру» випливає, що поняття «прокурор» охоплює всіх зазначених посадових осіб прокуратури. Отже, кримінальне процесуальне законодавство України прирівнює прокурора як процесуальну фігуру до прокурора в організаційному значенні як посадової особи органів прокуратури [11, с. 4]. Вважаємо, що ці поняття потребують певної конкретизації. Очевидно, що прокурором, уповноваженим на здійснення процесуального керівництва, має визнаватися не будь-який прокурор органів прокуратури, а конкретна посадова особа, відповідальна за конкретне кримінальне провадження. Суб'єкти нагляду мають визначатися згідно з організацією системи 
прокуратури, зазначеною Законом України «Про прокуратуру». Очевидно, що основним суб'єктом процесуального керівництва досудовим розслідуванням $є$ прокурори місцевих прокуратур та їх керівники. Роль регіональних прокурорів та Офісу Генерального прокурора у здійсненні процесуального керівництва обмежується тими кримінальними правопорушеннями, які вчинені в межах територіальної юрисдикції кількох прокуратур нижчого рівня або підслідні органам досудового розслідування відповідного рівня [5, с. 41-42]. Щодо цього варто зазначити, що одним із правил допустимості доказів є здійснення досудового розслідування належним суб'єктом. Відповідно, задля недопущення в майбутньому визнання судом зібраних у кримінальному провадженні доказів, недопустимих через порушення правил дотримання підслідності, суттєвою умовою допустимості доказів є здійснення досудового розслідування належним суб'єктом.

Звернемо увагу на те, що закон не встановлює граничного терміну, протягом якого прокурор має вирішити питання про підслідність. Отже, в цій ситуації останній має керуватися поняттям «розумні строки», що дає йому змогу вирішувати це питання в межах строку досудового розслідування. На наше переконання, це неправильно, адже порушення правил підслідності призводить до зниження його фаховості. Задля уникнення такої законодавчої прогалини М.А. Погорецький та С.Г. Волкотруб пропонують встановити строк для сповіщення слідчим прокурора про виявлену непідслідність кримінального провадження та подати прокурору клопотання про визначення підслідності, яке має бути вирішене негайно, але не пізніше 24 годин [12, с. 78].

Слід визнати теоретично обгрунтованою (за аналогією зі змістом ст. 220 КПК України «Розгляд клопотань під час досудового розслідування») позицію О.О. Цимбалістенка щодо доцільності передбачення для виконання прокурором повноважень з визначення підслідності та місця проведення досудового розслідування граничний термін, а саме 3 дні від дня, коли слідчий розпочав досудове розслідування кримінального правопорушення, не віднесеного до його підслідності [5, с. 84-85]. Однак ми вважаємо її досить обгрунтованою тим простим фактом, що розслідування кримінального правопорушення з порушеннями правил підслідності знижує ефективність кримінального провадження, може привести до суттєвих порушень кримінального процесуального закону, затягування строків досудового розслідування тощо. Одночасно зберігається ризик несвоєчасної кваліфікації, що не дає змоги визначити підслідність кримінального правопорушення.

Розглянуте вище питання перебуває в нерозривному взаємозв'язку з іще одним загальним положенням досудового розслідування, а саме місцем проведення досудового розслідування. Відповідно до ч. 1 ст. 218 КПК України досудове розслідування здійснюється слідчим того органу досудового розслідування, під юрисдикцією якого перебуває місце вчинення кримінального правопорушення. Структура цієї норми закону побудована таким чином, що повноваження прокурора з визначення місця проведення досудового розслідування передбачені в ч. 3 ст. 218 КПК України.

У правозастосовній діяльності прокурор наділяється вказаним повноваженням у тому разі, коли місце вчинення кримінального правопорушення невідоме або його вчинено за межами України, відповідно, виникає питання щодо визначення компетенції слідчого відповідного органу досудового розслідування. Критеріями визначення прокурором місця проведення досудового розслідування є місце виявлення ознак кримінального правопорушення; місце перебування підозрюваного чи більшості свідків; місце закінчення вчинення кримінального правопорушення або настання його наслідків тощо. За наявності однієї з таких ознак прокурор може прийняти очевидне рішення, але за наявності кількох із них прокурор має керуватися власним переконанням та досвідом з урахуванням усіх установлених обставин учинення кримінального правопорушення. Досліджуючи аналогічне питання, А.Ф. Смирнов пропонує в таких випадках під час визначення підслідності керуватися не територіальною ознакою, а тими завданнями, які вирішуються органами досудового розслідування [12, с. 99]. Як і в питанні щодо визначення підслідності, час на вирішення прокурором місця проведення досудового розслідування національним законодавством не встановлено. 3 урахуванням потреби забезпечення швидкого, повного та неупередженого розслідування вважаємо за можливе застосовувати сформульований нами раніше триденний строк для вирішення цього питання.

Висновки. Отримані результати проведеного дослідження свідчать про те, що положення КПК України, які регламентують підслідність та місце проведення досудового розслідування, $\epsilon$ одними з умов дотримання законності. Задля усунення наявних сьогодні законодавчих прогалин і неточностней, які негативно позначаються на правозастосовній практиці, законотворцям слід внести відповідні зміні та доповнення до КПК України. 
На нашу думку, вимога дотримання правил підслідності закріплена задля забезпечення належного та швидкого проведення досудового розслідування відповідним уповноваженим органом. Інакше неправильне визначення підслідності приводить до затягування досудового розслідування задля виправлення цих порушень, недостатньої компетентності розслідування тощо. Отже, на прокурора як процесуального керівника покладено обов'язок правильно й точно визначити підслідність відповідного кримінального правопорушення задля спрямування відповідних матеріалів точно за належністю.

\section{Список використаних джерел:}

1. Омаров А.А. Інститут підслідності в кримінальному провадженні : дис. ... канд. юрид. наук : спец. 12.00.09. Харків, 2017. 214 с.

2. Січко С.О. Актуальні питання підслідності кримінальних проваджень. Південноукраїнський правничий часопис. 2019. № 1. С. 32-35.

3. Погорецький М.А., Гринюк В.О. Визначення прокурором підслідності кримінального провадження. Вісник кримінального судочинства. 2016. № 3. С 60-68.

4. Дрозд В.Г. Правове регулювання досудового розслідування: проблеми теорії та практики : монографія. Одесса : Видавничий дім «Гельветика», 2018. 448 с.

5. Цимбалістенко О.О. Організаційно-правові основи прокурорського нагляду за додержанням законів на початковому етапі досудового розслідування : дис. ... канд. юрид. наук. Харків, 2017. $262 \mathrm{c.}$

6. Лапкін А.В. Основи прокурорської діяльності в Україні : навчальний посібник у схемах. 3-тє вид., змін. та доп. Харків : Право, 2015. 148 с.

7. Марчук Н.В. Організаційно-правові основи діяльності прокурора у досудовому кримінальному провадженні : дис. ... канд. юрид. наук : спец. 12.00.10. Харків, 2012. 244 с.

8. Омаров А.А. Щодо деяких проблемних питань процедури передачі кримінальних проваджень за підслідністю. Науковий вісник Херсонського держсвного університету. 2016. Вип. 3. T. 2. C. $114-117$.

9. Татаров О.Ю. Ваші докази недопустимі або чому розслідування може стати незаконним. Блоги LIGA.NET. URL: https://blog.liga.net/user/otatarov/article/31640.

10. Про затвердження Порядку ведення єдиного обліку в органах (підрозділах) поліції заяв і повідомлень про кримінальні правопорушення та інші події : Наказ МВС України від 8 лютого 2019 p. № 100. URL: https://zakon.rada.gov.ua/laws/show/z0223-19\#Text.

11. Марчук Н.В. Щодо визначення поняття «прокурор» в кримінальному провадженні. Вісник прокуратури. 2012. № 8. С. 3-10.

12. Погорецький М.А., Волкотруб С.Г. Удосконалення кримінального процесуального законодавства України щодо підслідності органів досудового розслідування. Вісник кримінального судочинства. 2017. № 1. С. 71-80.

13. Смирнов А.Ф. Некоторые вопросы подследственности уголовных дел на транспорте. Уголовно-процессуальные формы борьбы с правонарушениями: межвузовский сборник научных трудов Свердловского юридического института. 1983. № 139. С. 97-100. 